\title{
Influence of stock on physical and chemical traits of fresh apricot fruit**
}

\author{
T. Milošević ${ }^{1}$, N. Milošević ${ }^{2}$, I. Glišić ${ }^{1}$, and G. Šekularac ${ }^{1}$ \\ ${ }^{1}$ Department of Fruit Growing and Viticulture, Faculty of Agronomy, 32000 Cacak, Serbia, \\ ${ }^{2}$ Department of Pomology and Fruit Breeding, Fruit Research Institute, 32000 Cacak, Serbia
}

Received March 15, 2011; accepted April 20, 2011

\begin{abstract}
A b stract. The study was conducted to determine the effects of Myrobalan rootstock and Blackthorn interstock on fruit physical and chemical traits of five apricot cultivars. The results showed that cultivars grafted on Myrobalan rootstock appear to induce a higher fruit mass when compared with the Blackthorn interstock. Blackthorn interstock showed a tendency to induce a higher soluble solids/titratable acidity ratio than Myrobalan. Values of soluble solids content, total sugars, titratable acidity and fruit firmness between Myrobalan rootstock and Blackthorn interstock were not significant. Regarding cultivars, the greatest fruit mass observed in Roxana in both treatments, and the lowest in Biljana on Myrobalan and in Vera on Blackthorn. The lowest soluble solids, total sugars and soluble solids/titratable acidity ratio were found in Roxana in both variants of grafting, whereas the greatest titratable acidity also observed in Roxana in both cases, respectively. Based on the results from this study, the fruits of Roxana can be recommended for fresh consumption, whereas fruits of the other cultivars can be recommended for processing.

K e y w o r d s: apricot, cultivars, physical and chemical traits, interstock, rootstock
\end{abstract}

\section{INTRODUCTION}

Apricot (Prunus armeniaca L.) is one of the most important and desirable of the temperate tree fruits both worldwide (Martínez-Mora et al., 2009). Serbia produced $31157 \mathrm{t}$ of apricots in 2009 (FAOSTAT, 2010). The most important apricot-growing area in Serbia is the Cacak region located in Western Serbia. Apricots are cultivated worldwide mainly for their high-quality fruit, which is consumed fresh, processed by the food industry, or preserved by drying. For this reason, apricot has an important place in human nutrition. Moreover, the apricot fruit is not only consumed fresh but also used to produce dried apricot, frozen apricot, jam, jelly, marmalade, pulp, juice, nectar and extrusion products (Jannatizadeh et al., 2008).

*Corresponding author e-mail: tomom@tfc.kg.ac.rs

**This work is part of the 31064 project financially supported by the Ministry of Science of the Republic of Serbia, 2011-2014.
Fruit quality is a combination of physical and chemical characteristics accompanied by sensory properties (appearance, texture, taste and aroma), nutritional values, chemical compounds, mechanical properties and functional properties (Ruiz and Egea, 2008). Therefore, fruit apricot cultivars must be characterized by fruit quality traits which satisfy the consumers (Crisosto et al., 2004). However, fruit quality is affected by a number of pomological traits that cannot be analyzed separately from the biological properties of the fruit tree and the yield obtained, agronomical and ecological factors and their correlations (Licznar-Małańczuk and Sosna, 2005). In addition, a great number of authors reported that the cultivar and rootstock or interstock have an important role in the physical and chemical traits of apricot fruit (Djuric and Keserovic, 1999; Kapel et al., 2004; Hernández et al., 2010).

The aim of this study was to assess if some physical and chemical fresh fruit traits are affected by rootstock or interstock under Serbian conditions.

\section{MATERIALS AND METHODS}

Three Serbian (Aleksandar, Biljana and Vera) and two introduced (Harcot and Roxana) apricot cultivars were evaluated in an experimental orchard from 2008 to 2010. This choice was due to the possible interest in these cultivars in the Cacak Region, because of their maturity time and good fruit quality. The cultivars were grafted onto Myrobalan seedlings (Prunus cerasifera Ehrh.) and Blackthorn interstock (Prunus spinosa L.) in an experimental orchard located in Prislonica near Cacak, Western Serbia (43 $53^{\prime} \mathrm{N}$, $20^{\circ} 21^{\prime} \mathrm{E}, 340 \mathrm{~m}$ a.s.1.). Trees were planted in 2007 at a $5.5 \mathrm{~m}$ $\times 3.0 \mathrm{~m}\left(606\right.$ trees $\left.^{-1}\right)$; the training system was open vase with three basic branches and was pruned throughout the experiment. The experiment was established in a randomized 
block design with five trees in four replications for each stockscion and stock-interstock-scion combination. The physical and chemical traits were evaluated over three years (20082010), ie from the second to the fourth year after planting.

Fruit mass (FM) was determined using a Tehnica ET-1111 (Iskra, Slovenia) in 20 randomly selected fruits in four replications for each stock-scion and stock-interstockscion combination. Fruit chemical and sensorial traits such as soluble solids content (SS), total sugars content (TS), titratable acidity (TA), soluble solids/titratable acidity ratio $(\mathrm{SS} / \mathrm{TA}$ ratio $=\mathrm{RI})$ and flesh firmness $(\mathrm{FF})$ were measured immediately after picking (commercial maturity stage). The SS ( ${ }^{\circ}$ Brix) was determined at $20^{\circ} \mathrm{C}$ with a Milwaukee MR 200 (ATC, Belgium) hand refractometer. The TS was determined using the Luff-Schoorl method and is expressed as percentage of fresh mass, while the TA was measured by neutralization to $\mathrm{pH} 7.0$ with $0.1 \mathrm{~N} \mathrm{NaOH}$ as percentage of malic acid. On the basis of the measured data, the SS/TA ratio was calculated. The FF $\left(\mathrm{kg} \mathrm{cm}^{-2}\right)$ was measured on opposite paired cheeks (where the skin was removed) using a Bertuzzi penetrometer (model FT-327, Facchini, Alfonsine, Italy) equipped with an 8-mm cylindrical plunger.

The data obtained were statistically analyzed using analysis of variance (ANOVA). The treatment means were compared using the least significant difference (LSD) test at $\mathrm{p} \leq 0.05$ and the MSTAT-C statistical computer package (Michigan State University, East Lansing, MI, USA).

\section{RESULTS AND DISCUSSION}

The values of the major fruit physical and chemical traits for Myrobalan rootstock and Blackthorn interstock grafted with five apricot cultivars in the fourth year (2010) after planting are presented in Table 1. Differences between rootstock and interstock for the FM were statistically significant. Namely, Myrobalan induced a higher mean FM than Blackthorn. The difference was $34.29 \%$ for all the evaluated cultivars. In the stock-scion or stock-interstockscion combinations, the highest FM was observed in cv. Roxana. In the case of Myrobalan, the lowest FM was registered in cv. Biljana, whereas in the case of Blackthorn interstock, cv. Vera had the lowest value. On this combination cvs Aleksandar and Biljana had a similar fruit size. Fruit mass is a major quantitative factor determining yield, fruit quality and consumer acceptability (Ruiz and Egea, 2008). In the present study, Myrobalan rootstock induced higher FM than Blackthorn interstock. On the other hand, the early ripening cvs. Aleksandar, Biljana and Vera produced smaller fruits than late ripening cv. Roksana which is in accordance with results obtained by Djuric and Keserovic (1999). This seems to represent a major advantage for the growers. Also, Licznar-Małańczuk and Sosna (2005) reported that fruit mass depended on the cultivar and on the crop load, and also on the rootstock and on the pruning system (Kapel, 2003). Previous studies also demonstrated the high variability of this parameter among apricot cultivars (Jannatizadeh et al., 2008; Hernández et al., 2010).

T a b I e 1. Influence of Myrobalan rootstock and Blackthorn interstock on fruit quality traits of cvs. Aleksandar, Biljana, Vera, Harcot and Roxana apricot cultivars in the fourth year (2010) after planting

\begin{tabular}{|c|c|c|c|c|c|c|c|}
\hline Treatment & Cultivar & FM (g) & SS ( ${ }^{\circ}$ Brix $)$ & TS (\%) & TA (\%) & $\mathrm{SS} / \mathrm{TA}$ & $\mathrm{FF}\left(\mathrm{kg} \mathrm{cm}^{-2}\right)$ \\
\hline & Aleksandar & $74.02 \mathrm{~d}$ & $17.49 \mathrm{a}$ & $11.97 \mathrm{~b}$ & $0.64 \mathrm{~d}$ & $27.33 \mathrm{a}$ & $1.40 \mathrm{a}$ \\
\hline & Biljana & $71.20 \mathrm{e}$ & $16.15 \mathrm{a}$ & $13.02 \mathrm{a}$ & $0.73 \mathrm{c}$ & $22.12 \mathrm{~b}$ & $2.04 \mathrm{a}$ \\
\hline \multirow[t]{3}{*}{ Myrobalan } & Vera & $79.46 \mathrm{c}$ & $16.16 \mathrm{a}$ & $13.01 \mathrm{a}$ & $0.58 \mathrm{e}$ & $27.86 \mathrm{a}$ & $2.22 \mathrm{a}$ \\
\hline & Harcot & $82.45 \mathrm{~b}$ & $16.44 \mathrm{a}$ & $9.70 \mathrm{c}$ & $0.93 \mathrm{~b}$ & $17.68 \mathrm{c}$ & $1.90 \mathrm{a}$ \\
\hline & Roxana & $99.25 \mathrm{a}$ & $12.97 \mathrm{~b}$ & $6.63 \mathrm{~d}$ & $1.12 \mathrm{a}$ & $11.58 \mathrm{~d}$ & $1.34 \mathrm{a}$ \\
\hline \multirow[t]{3}{*}{ Mean } & & $81.28 \mathrm{~A}$ & $15.84 \mathrm{~A}$ & $10.87 \mathrm{~A}$ & $0.80 \mathrm{~A}$ & $21.31 \mathrm{~B}$ & $1.78 \mathrm{~A}$ \\
\hline & Aleksandar & $47.40 \mathrm{c}$ & $17.40 \mathrm{a}$ & $12.11 \mathrm{c}$ & $0.61 \mathrm{e}$ & $28.52 \mathrm{a}$ & $1.44 \mathrm{a}$ \\
\hline & Biljana & $46.60 \mathrm{c}$ & $16.00 \mathrm{~b}$ & $13.10 \mathrm{a}$ & $0.69 \mathrm{c}$ & $23.19 \mathrm{a}$ & $2.11 \mathrm{a}$ \\
\hline \multirow[t]{3}{*}{ Blackthorn } & Vera & $43.90 \mathrm{~d}$ & $16.00 \mathrm{~b}$ & $12.96 \mathrm{~b}$ & $0.64 \mathrm{~d}$ & $25.00 \mathrm{a}$ & $2.03 \mathrm{a}$ \\
\hline & Harcot & $57.33 \mathrm{~b}$ & $16.40 \mathrm{ab}$ & $9.81 \mathrm{~d}$ & $0.79 \mathrm{~b}$ & $20.76 \mathrm{ab}$ & $1.88 \mathrm{a}$ \\
\hline & Roxana & $71.80 \mathrm{a}$ & $13.35 \mathrm{c}$ & $6.49 \mathrm{e}$ & $0.99 \mathrm{a}$ & $13.48 \mathrm{~b}$ & $1.61 \mathrm{a}$ \\
\hline Mean & & $53.41 \mathrm{~B}$ & $15.83 \mathrm{~A}$ & $10.88 \mathrm{~A}$ & $0.74 \mathrm{~A}$ & $22.19 \mathrm{~A}$ & $1.81 \mathrm{~A}$ \\
\hline
\end{tabular}

The same small letters in columns shows insignificant differences $(\mathrm{p} \leq 0.05)$ by LSD test among cultivars; the same capital letters in columns shows insignificant differences $(\mathrm{P} \leq 0.05)$ by LSD test between Myrobalan rootstock and Blackthorn interstock; FM - fruit mass, SS - soluble solids content, TS - total sugars content, TA - titratable acidity, SS/TA - soluble solids/titratable acidity ratio, FF - flesh firmness. 
The differences between rootstock and interstock for mean SS, TS and TA values were insignificant at $\mathrm{P} \leq 0.05$ (Table 1). However, in the case of Myrobalan rootstock, the lowest SS was found in cv. Roxana, whereas the highest and similar values were registered in all the other cultivars. On the other hand, Blackthorn induced the highest SS content in cv. Aleksandar, although all of them did not differ significantly when compared with cv. Harcot. The lowest SS was observed in cv. Roxana.

Myrobalan gave higher TS in cvs. Biljana and Vera than the other cultivars. The lowest TS observed in cv. Roxana. In the case of Blackthorn, the highest TS were found in cV. Aleksandar and the lowest also in cv. Roxana. The TA in apricot fruit was the greatest in cv. Roxana on the stockscion and stock-interstock-scion combinations, whereas the lowest TA was exhibited by cv. Vera on Myrobalan, and in cv. Aleksandar on Blackthorn.

The values of SS, TS and TA were similar on Myrobalan and on Blackthorn. Nevertheless, all cultivars in both treatments showed SS values higher than $12^{\circ}$ Brix. Some authors reported that apricot genotypes which have a SS content $12^{\circ}$ Brix were characterized by an excellent gustative quality (Ruiz and Egea, 2008). The above-mentioned authors also found that the soluble solids content is a very important quality attribute, influencing notably the fruit taste. Moreover, Asma et al. (2007) reported that the genotype has an important effect on the SS content, which was confirmed by results in our study. In addition, our range of values of TS is in an agreement with previous work on apricot (Audergon et al., 1990), but the values are generally lower than those for a group of Turkish genotypes (Asma et al., 2007). The differences between our results and those of the above-mentioned authors were likely due to the different ecogeographical groups of apricot genotypes studied and impact of environmental conditions.

Several authors have reported similar type of results for some fruit crops (Manjuantha et al., 2012).

In the present study, Myrobalan and Blackthorn produced a similar TA content. Hernández et al. (2010) also reported that TA in apricot fruit was not significantly affected by the rootstock. Ruiz and Egea (2008) stated that the fruit maturity stage at the harvest date is the principal factor affecting fruit acidity and also SS content. The range of TA values obtained in this study is in an agreement with previous work on apricot (Audergon et al., 1990).

Data in Table 1 showed that Blackthorn yielded a significantly higher mean SS/TA ratio (RI) than Myrobalan at $\mathrm{P} \leq 0.05$. In the case of Myrobalan, the greatest RI was found in cvs. Aleksandar and Vera, and the lowest in cv. Roxana. Blackthorn produced the highest RI in cvs. Aleksandar, Biljana and Vera, although none of them differed significantly when compared with cv. Harcot. The lowest RI was found also in cv. Roxana. In general, Blackthorn induced a higher RI than Myrobalan. In addition, the FF was not significantly affected by the rootstock and/or interstock.

The relationship between SS and TA (RI) has an important role in consumer acceptance of some apricot, peach, nectarine and plum cultivars, as it has been previously mentioned (Ruiz and Egea, 2008). Crisosto et al. (2004) reported that in the case of cultivars with TA $>0.90 \%$ and $\mathrm{SS}<12.0 \%$, consumer acceptance was controlled by the interaction between TA and SS rather than SS alone. In general, our range values of these substances and relationship between them were better than the values of the abovementioned authors.

Regarding FF, Myrobalan and Blackthorn exhibited fruits of a similar consistency with all tested cultivars. Nevertheless, none of the rootstock and interstock induced to firmness lower than $0.5 \mathrm{~kg} \mathrm{~cm}^{-2}$. According to Scandella et al. (1998) the quality standards for apricot at harvest maturity, suitable for consumers and the apricot industry, are a firmness value between 3.0 and $0.5 \mathrm{~kg} \mathrm{~cm}^{-2}$, which was confirmed by the results in this study.

\section{CONCLUSIONS}

1. The fruit mass ranged from 53.41 to $81.28 \mathrm{~g}$. Among cultivars, Roxana had the highest fruit mass ie 71.80 and $99.25 \mathrm{~g}$ on Blackthornon and Myrobalan, respectively.

2. The soluble solids, total sugars content, titratable acidity and firmness of fruits between Myrobalan and Blackthorn were not significantly different.

3. The soluble solids/titratable ratio or ripening index varied from 21.31 to 22.19 units between Myrobalan and Blackthorn. Aleksandar fruits had the highest values (27.33 and 28.52).

4. The fruit cultivars had the highest:

- Aleksandar - soluble solids content (17.40 and $17.49^{\circ}$ Brix),

- Biljana - total sugars content (13.02 and 13.10\%),

- Roxana - titratable acidity values (0.99 and 1.12\%).

5. Fruit firmness among the cultivars was not significantly different.

\section{REFERENCES}

Asma B.M., Kan T., and Birhanli O., 2007. Charaterization of promising apricot (Prunus armeniaca L.) genetic resources in Malatya, Turkey. Genet. Resour. Crop Evol., 54, 205-212.

Audergon J.M., Souty M., and Breuils L., 1990. Breeding for the production of high-quality apricots. Proc. 9th Sci. Conf. Qualite des fruits frais, December 4-6, Avignon, France.

Crisosto C.H., Garner D., Crisosto G.M., and Bowerman E., 2004. Increasing 'Blackamber' plum (Prunus salicina Lindley) consumer acceptance. Postharvest Biol. Technol., 34, 237-244.

Djuric B. and Keserovic Z., 1999. Study on the possibilities of use of black thorn (Prunus spinosa L.) as an interstock in apricot. Acta Hortic., 488, 533-538. 
FAOSTAT, 2010. http://www.faostat.fao.org

Hernández F., Pinochet J., Moreno M.A., Martínez J.J., and Legua P., 2010. Performance of Prunus rootstocks for apricot in Mediterranean conditions. Sci. Hort., 124, 354-359.

Jannatizadeh A., Naderi-Boldaji M., Fatahi R., GhasemiVarnamkhasti M., and Tabatabaeefar A., 2008. Some postharvest physical properties of Iranian apricot (Prunus armeniaca L.) fruit. Int. Agrophysics, 22, 125-131.

Kapel F., 2003. Influence of pruning and interspecific Prunus hybrid rootstocks on tree growth, yield and fruit size of apricot. J. Am. Pom. Soc., 57, 100-106.

Licznar-Małańczuk M. and Sosna I., 2005. Evaluation of several apricot cultivars and clones in the lower Silesia climatic conditions. Part I: Blossoming of trees, yield and fruit quality. J. Fruit Ornam. Plant Res., 13, 39-48.

Manjuantha, S.S., Raju P.S., and Bawa A.S., 2012. Rheological behaviour of enzyme clarified Indian goose- berry juice. Int. Agrophys., 26, 145-151.

Martínez-Mora C., Rodríguez J., Cenis J.L., and Ruiz-García L., 2009. Genetic variability among local apricots (Prunus armeniaca L.). Spanish J. Agric. Res., 7, 855-868.

Ruiz D. and Egea J., 2008. Phenotypic diversity and relationships of fruit quality traits in apricot (Prunus armeniaca L.) germplasm. Euphytica, 163, 143-158.

Scandella D., Sibille I., Venien S., Lichou J., and Jay M., 1998. Abricot: Evaluation des atouts organoleptiques. Infos-Ctifl, $141,22-25$. 